\title{
Effect of Capital Structure of Nigeria Firms on Economic Growth
}

\author{
Dr. Nwankwo, Odi., FClB \\ Department of Banking and Finance, Kogi State University, Anyigba Kogi-Nigeria \\ Phone: 08035763229, E-mail: odinwankwo2002@yahoo.com
}

\section{Doi:10.5901/mjss.2014.v5n1p515}

\begin{abstract}
The efficiency of financial system is endogenously achieved if the capital structure of the economy can promote optimal use of the resources available for economic growth and development. The aim of this paper is to examine the effect of capital structure of firms on economic growth in Nigeria. A quantitative research design was used and regression analysis and ordinary least square in carrying out this study. The results of the study indicate that capital structure of firms in Nigeria has a long run relationship with the growth and development of Nigerian economy. The implication of this finding is that capital structure of a firm will help to increase the growth of the economy in the long run if well managed. It is therefore recommended that Nigerian firm should try and match their capital structure with real activities that will help to increase the level of economic growth in Nigeria; and that the firms should go for long term financing instead of going for short term loan or debt which form most of their leverage and as well focus on developing internal strategies that will help the economy to grow.
\end{abstract}

Keywords: Capital Structure, Cost of Debt, Cost of Equity, Economic Growth.

\section{INTRODUCTION}

In both developed and developing countries, there has been an argument on the effect of capital structure of a firm on firm performance and economic growth in general. Capital structure is one of the financial topic that has the important derives in terms of firms ability in fulfilling the needs of the stakeholders. It also represents the major clam in firm assets. Some of the researchers in the area of capital structure agreed with the theory of capital structure which states that capital structure of a firm have positive effect on the performance and as well as increase the growth of the country's economy (Dare and Sola, 2010; Sanghoon, 2008; Stephen and Stefan, 2001; Mminquan and Jianfuo, 2008; Aliu, 2010; Olokoyo, 2012; and Onwumere, Onudugo and Imo, 2013).

The efficiency of financial system is endogenously achieved if the capital structure of the economy can promote optimal use of the resources available for economic growth and development. Dare and Sola (2010) opines that there is positive relationship between capital structure and corporate performance of a firm. In another exposition, some researchers argues that capital structure has negative effective on firm performance which has link with the economic growth (Ogbulu and Emen, 2012; Patrick, Joseph and Kemi, 2013; Akinlo, 2011). Capital structure can be defined by Dare and Sola (2010) as the way a corporation can finance its assets through some combination of equity and debt. Sanghoon (2008) defined capital structure as the ratio of different finance. Capital available in a business to growth. There are two forms of capital: equity capital and debt capital. Under the firm of capital, there exist market capitalization, bank credit which has its own benefits and drawbacks and a substantial part of any organisation is aimed at finding the perfect capital structure in terms of risk and reward payoff for stakeholders. The effect of capital structure on economic growth of any country especially Nigeria has been in a contention.

Economic growth rate of change must entail consumption and investment of the firm. Economic growth can be defined as the steady growth in the productive capacity of the economy. It is the increase in the amount of the goods and services produced by an economy over time, the level of increase in economic growth is been attributed to the level of capital structure of firms in the country. This is because economic growth has been attributed to the accumulation of human and physical capital. Capital structure means the increase in long term debt and shareholders fund.

The important from above exposition is that there is still gap in the area of capital structure and economic growth in Nigeria and the study will contribute to the on-going debate. Therefore, in related terms, the essence of this paper is to investigate the factors or effect of capital structure determinate on economic growth in Nigeria. 


\section{Review of Related Literature}

The focus of this section is a review of related literature in terms of some studies that have been carried out to investigate and explain capital structure and its implication on firm and economic performance.

\subsection{Empirical Review}

Onwumere, Onudugo and Imo (2013) in a study of the relationship between financial structure and economic growth in Nigeria using regression analysis, it was revealed that total financial structure has positive and significant effect on economic growth in Nigeria. It was also discovered that the banking and capital market exert more influence on economic growth while insure sector were found to have no significant effect on economic growth.

In a study on the structure of the Nigeria banking sector and its impact on bank performance, Ugwunta , Ani , Ugwuanyi and Ugwu (2012) utilizes explanatory variables such as total deposit, concentration ratio in terms of deposit, the ratio of demand deposits to total deposit for the banking sector, the ratio of foreign assets to total asset and the number of banks while profitability was formally measured as Return On Assets (ROA) which serve as dependent variable. Regression analysis was employed and it was discovered that Nigerian banking sector is oligopolistic in structure and that market concentration is a major determinant of bank profitability in Nigeria.

Tinusa and Babalola (2012) used panel data methodology to investigate the impact of corporate governance on capital structure decision of Nigeria firms. The study found that corporate governance $\mathrm{h} s$ important implications on the financing decisions of the firm.

Akinleye (2012) made use of panel data in examining the speed of adjustment towards the target capital structure by Nigerian listed firms. It was discovered that firms adjust toward target leverage at a moderate speed, with a half-life of 3.9 year for book leverage, even after controlling for the determinants of capital structure and fixed effects.

Omorogie and Erah (2010) studied capital structure and corporate performance in Nigeria between 1995 and 2009 employing Ordinary Least Square (OLS) techniques of model estimation. It was found that capital structure has not sustained effective funding required for growth and development of corporates because of its high rate of growth.

Iwarere and Akinleye (2010) used descriptive survey to investigate capital structure determinants in the Nigerian banking industry. The result identifies credit rating, volatility of earning cash flow, financial distress, transaction costs, and financial flexibility as the important factor in choosing appropriate amount of debt for bank.

Olokoyo (2012) in a study of relationship between capital structure and corporate performance of Nigeria quoted firms the study employed panel data approach by using fixed effect estimation, random-effect estimation and pooled regression model and it was discovered that maturity structure of debts effect on performance of firms significantly and the size of the firm has a significant positive effect on the performance of firms in Nigeria.

Michael (2012) investigated capital structure determinant of quoted firms in Nigeria and lessons for corporate financing decisions using regression analysis of data obtained from Nigeria stock exchange fact book. it shows that capital structure is positively determined b cost of equity ,existence of debt tax shield, covenant restrictions in debt agreements, firm dividend policy, competitor's capital structure or mix and profitability and negativity correlated with cost of debt.

Akinlo (2011) examine the determinants of capital structure of 66 firms listed on the Nigerian stock exchange during the period of 1997 to 2007 musing panel data. The results shows that there is a negative relationship between leverage and growth opportunities and legibility, but negatively related to liquidity as well as size.

Patrick, Joseph and Kemi (2013) in a recent study on the impact of capital structure on firms performance in Nigeria using fixed effect regression estimation model. It was discovered that there is positive relationship between return on investment and leverage of the firm over a period of ten years. Their result support the traditional theory of capital structure which asserts that leverage is a significant determinant of firm performance.

Babalola (2012) used ordinary least square in investigating the effects of optimal capital structure on firms' performance in Nigeria. It was discovered that there is a relationship between optimal capital structure under trade-off theory and the optimal capital structure of manufacturing firms.

Ogbulu and Emeni (2012) investigated the determinants of corporate capital structure in Nigeria using ordinary least-square method and cross sectional survey; it was found that size has a negative and significant influence on capital structure

Dare and Sola (2010) examine the relationship between capital structure and corporate performance in Nigeria petroleum industry using fixed-effect estimation, Random-effect estimation and maximum likelihood estimation. It was 
found that there was positive relationship between earnings per share and leverage ratio on one hand and positive relationship between dividend per share and leverage ratio on the other hand.

\subsection{Theatrical Framework}

There are many theories which seek to explain the behaviour of capital structure and it effect on economic growth of any country for the purpose of this study, the theories that are considered relevant include exogenous growth theory, capital structure theory and trade-off theory.

\subsubsection{Exchange Growth Theory}

Exogenous Growth Theory (channels to growth model) was developed from the two views of endogenous growth theory ("AK" growth model and Schumpeterian growth model). The channels to growth model tries to link the financial intermediaries' function of pension fund managers to economic growth. The endogenous growth "AK" model offered by Pagano (1993) states that financial intermediation could affect economic growth through three channels namely: changing productivity of capital, savings funneled to investment and savings rate. The Schumpeterian growth model is focused on technological innovations as channels through which economic growth could be affected.

The channels to economic growth model offer important insight into channel through which financial structure affects economic growth. The endogenous growth theory (channels to growth model) states that well developed capital structure can promote economic growth through cost of equity and debt.

\subsubsection{Capital Structure Theory}

This theory was developed by Modigliani and Miller theory in (1985) and states that, under a certain market price process, in the absence of taxes, bankruptcy costs, agency costs, and asymmetries information and in an efficient market, the value of a firm is unaffected by how that firm is financed. This means that market value of a firm is determined by its earning power and the risk of its underlying assets and it is independent of the way it chooses to finance its investment or distribute dividends. The theory become more complicated but the basic idea is that, under normal circumstances, it makes no difference whether a firm finances itself with debt or equity.

\subsubsection{Trade-Off Theory of Capital Structure}

This theory was developed in 1999 by Shyam Sunder by criticing the assumption used by Modigliani and Miller. This theory states that M.M. Theory or assumption is not realistic and that the trade-off theory determines an optimal capital structure by adding taxes cost of financial distress and agency cost but retains the assumptions of market efficiency which suggest that firm target leverage is driven. This theory is based on the inability of capital market to perform well and it is associated with advantages and disadvantages of using debt capital.

\section{Methodology}

The data used in this study were collected through secondary source. The data were generated from Central Bank of Nigeria (CBN) and Nigeria Stock Exchange (NSE) Factbook from 1987 to 2012. In this study, employ the use of two (2) explanatory variables and one (1) dependent variable. In our model specification, economic growth was proxied by Gross Domestic Product (GDP) and depends on Cost of Debt (COD) and Cost of Equity (COE). The model is modified below:

$\mathrm{GDP}=\mathrm{f}(\mathrm{COD}, \mathrm{COE}) \ldots 1$

$\mathrm{GDP}=\beta_{1}+\mathrm{X}_{1} \mathrm{COD}+\mathrm{X}_{2} \mathrm{COE}+\mu_{1}$

Where

GDP $=$ Gross Domestic Product

COD $=$ Cost of Debt

$\mathrm{COE}=$ Cost of Equity

$\beta_{1}=$ Regression Coefficient

$\mathrm{X}_{1}-\mathrm{X}_{2}=$ Parameter Estimation

$\mu=$ Error term 
The above model means that the positive effect is expected between capital structure and economic growth in Nigeria between 1987 to 2012.

\section{Data Analysis}

The summary of the capital structure regression from ordinary least square analysis is shown below in table 1.

\begin{tabular}{lllll}
$\begin{array}{l}\text { Dependent Variable: LOG(GDP) } \\
\text { Method: Least Squares } \\
\text { Sample: 1987 2012 } \\
\text { Included observations: 26 }\end{array}$ & & & & \\
\hline \hline Variable & Coefficient & Std. Error & t-Statistic & Prob. \\
\hline \hline C & -1.195892 & 1.717330 & -0.696367 & 0.0000 \\
LOG(COD) & 0.759563 & 0.459882 & 1.651648 & 0.0002 \\
LOG(COE) & -0.345186 & 0.837325 & -0.004187 & 0.0234 \\
\hline \hline R-squared & 0.983524 & Mean dependent var & 0.527975 \\
Adj. R-squared & 0.937463 & S.D. dependent var & 1.322079 \\
S.E. of regression & 1.253280 & Akaike info criterion & 3.397573 \\
Sum squared resid & 36.12637 & Schwarz criterion & 3.542738 \\
Log likelihood & -41.16845 & Hannan-Quinn criter. & 3.439375 \\
F-statistic & 24.536147 & Durbin-Watson stat & 1.316729 \\
Prob(F-statistic) & 0.000000 & & & \\
\hline \hline
\end{tabular}

\section{Source: E-view 7.0}

The result obtained above shows that the estimation of the variables conforms to the a priori expectation. This is because the dependent variable: economic growth has an autonomous value of -1.195892 and has a positive relationship with cost of debt (COD) while it has negative relationship with cost of equity (COE).

Considering the sign and size of the coefficient, there is a long run relationship between dependent variable (GDP) and the independent variables (COD and COE) within the period under review 1987-2012. The result above displays a regression result of the effect of capital structure on economic growth in Nigeria. As specified above, the results were obtained using the ECM and the Ordinary Least Square (OLS) method of estimation which test for the short run equilibrium dynamics of the variables. From the empirical evidence, we can say that the coefficient of the regression which is the coefficient that depicts the estimated coefficient appears to be good while standard error and the values of tstatistic have been shown.

The results of other important statistical tools revealed that: the coefficient of determination $\left(R^{2}\right)$ as used to measure the success of the regression in predicting the value of the dependent variable within the sample and tests the goodness of fit, which is considered high in this study over $98 \%$; the adjusted R-square, the Durbin-Watson statistic, and the entire regression test is statistically significant including the F-test under $5 \%$ level of significance.

The result indicates that the level of cost of debt ratio over the years have significant positive impact on the growth of Nigerian economy while cost of equity have negative and significant effect on economic growth in Nigeria.

A close examination at the result of the equation reveals that some signs were in line with the opinion expectation in literature review. From the result, cost of debt ratio (COD) satisfy one condition by having positive sign while cost of equity ratio $(\mathrm{COE})$ which is negative satisfies another condition. This means that the independent variables are in line with the opinion expectation in the model.

From the result, the difference in beta coefficient of the variables representing the indicators of capital structure in Nigeria shows the different contributions of the variables to the growth of Nigerian economy (GDP). In this result, using the beta coefficient, GDP is negative at constant of -1.195892 . This means that when all variables are held constant, there will be a negative variation up to the tune of 1.195892 units in GDP. Similarly, a unit change in cost of equity (COE) when all variables are held constant will lead to a decrease in GDP by -0.345186 units. This is because of its negative impact to the GDP.

\section{Conclusion and Recommendations}




\subsection{Conclusion}

The difference between capital structure of Nigerian firms and economic growth in developed economies is that Nigerian firms prefer short-term loan and have low amount of long term debt that will encourage the growth of Nigerian economy. This is because Nigeria firms are fully relying mainly on short term financing rather than long term financing. The empirical result from this study revealed that effective capital structure of Nigerian firm will help to increase the level of economic growth in the country and the cost of debt which is measured in either before or after-tax cost is seen to have positive and significant effect on economic growth in Nigeria, while cost of equity which is the rate of return a firm pay to its shareholders as a compensate for the risk they undertake by investing their capital appears to have negative and significant effect on the growth of Nigerian economy.

The overall result indicates the support of the exogenous growth theory, capital structure theory of irrelevance and trade-off theory of capital structure and we therefore conclude that there is a long run effect of capital structure of Nigeria firms on economic growth in Nigeria.

\subsection{Recommendations}

In line with the finding of the study, the following recommendations are made:

1. Nigerian firm should try and match their capital structure with real activities that will help to increase the level of economic growth in Nigeria.

2. That the firm should go for long term financing instead of going for short term loan or debt which form most of their leverage and as well focus on developing internal strategies that will help the economy to grow.

3. The issue of the level of effect of capital structure on economic growth needs to be look into because of the negative effect of cost of equity on growth in Nigeria.

\section{References}

Akinleye, A. K. (2012). Speed of adjustment towards the target capital structure by Nigerian listed firms. Journal of Emerging Trend in Economics and Management Science (JETEMS), 3(5): 419-494.

Akinlo, O. (2011). The determinants of capital structure evidence from Nigeria panel data. African Economy and Business Review,9(1):1-16

BAbalola ,t.a(2012). The effects of optimal capital structure on firms' performance in Nigeria. Journal of Emerging Trend in Economics and Managemnt Sciences (JETEMS), 3(2):131-133

Dare, F. D. and Sola, O. (2010). Capital Structure and Corporate Performance in Nigeria Petroleum Industry: Panel Data Analysis. Journal of Mathematics and Statistics, 6(2): 168-173

Iwarere, H. T. and Akinleye, G. T. (2010). Capital Structure Determinants in the Nigeria Banking Industry: Financial Managers Perspective. Pakistan Journal of Social Sciences, 7(3): 205-213.

Micheal, N. B. (2012). Capital structure determinants of quoted firms in Nigeria and lesson for corporate financing decisions. Journal of Finance and Investment Analysis, 1(2):61-81.

Minaquan, I. and Jiantuo, T. (2008). Financial Structure, Distribution in the People's Republic of china. Asian Development Review, 25(1-2): 137-155

Ogbulu, O. M. and Emeni, F. K. (2012). Determinants of corporate capital structure in Nigeria. International Journal of Economics and Management Sciences, 1(10):81-96.

Olokoyo, F. O. (2012). Capital Structure and Corporate Performance of Nigerian Quoted Firms. A Panel Data Approach. Published Ph.D Thesis presented to the Department of Banking and Finance, School of Business, College of Development Studies, Covenant University, Ota, Ogun State Nigeria.

Omorogie, A. N. and Erah, D. O. (2010). An Empirical Investigation of Capital Structure and Corporate Performance in Nigeria. Journal of Management Sciences, 1(1): 43-52

Onwumere, J. U. J., Onudugo, V. and Imo, G. I. (2013). Financial Structure and Economic Growth: Evidence from Nigeria. Global Journal of Management and Business Research Finance, 13(5):1-9

Patrick, O., Joseph, O. and Kemi, A. (2013). The impact of capital structure on firms' performance in Nigeria. Munich Personal REPEC Archive (MPRA)1-24.

Sanghoon, I. (2008). Ownership Structure and Financial Performance : Evidence from Panel Data of South Korea. Journal of Social and Management Sciences,6(10):1-43

Tinusa, O. G. and Babalola, A. Y. (2012). The Impact of Corporate Governance on Capital Structure Decision of Nigerian Firms. Research Journal in Organisational Psychology and Educational Studies, 3(2):121-128

Ugwunta, D. O., Ani, W. U., Ugwuanyi, G. O. and Ugwu, J. N. (2012). The Structure of Nigeria Banking Sector and its impact on bank performance. Journal of Economics and Sustainable Development, 3(7): 30-40 
